\title{
Developing Pedagogies of Interreligious Understanding
}

\author{
Judith A. Berling
}

The essays in this volume were developed in conversations over a period of years by participants in a project on "Interreligious Education and Pedagogy." Project participants shared their own experiences of developing and evaluating interreligious programs, their successes and their frustrations. They learned from and with one another, and several of them participated in panels at professional associations or contributed essays to volumes on interreligious pedagogies. They sought out conversations with educators and essays by faculty from institutions and backgrounds beyond their own.

The project also sponsored a research report mapping the current state of interreligious learning in theological schools and seminaries. The report expanded upon the contributions of project participants with a thorough review of published literature and in-person or online interviews with faculty from a wider group of institutions. Each institution has had its own distinctive journey of challenges and opportunities, which has shaped its approach/es to interreligious education. That report is soon to be posted on the website of the GTU.

This brief chapter will reflect on the pedagogical issues and implications of the essays in this volume, informed by the broader research of the project.

\section{Overcoming the Obstacle of Monotheistic Exclusivism}

This volume, and the project which developed it, focused primarily on theological schools and seminaries, and primarily on Christian, Jewish, and Muslim programs of interreligious education. Given that focus, initiatives in interreligious education had to break free from historic constraints against positive views of other religions, constraints that are deeply embedded in the mainstream histories of these three great traditions. Reuven Firestone's essay addresses this issue head-on, exploring how the historical rise of monotheism positioned monotheistic religions to argue against and/or condemn other 
religions. But he goes on to argue that in the post-enlightenment era, some educated adherents of monotheistic religions have become increasingly aware that their tradition is embedded in rich cultural diversity, a vast array of different knowledges, and many sophisticated religions. In his view, and given that awareness, it is important for students, especially seminary students, to recognize that as powerful and authentic as their own tradition is, it does not contain all knowledge or wisdom. Learning something of the wisdom of other traditions not only cultivates appropriate spiritual humility (there is always more to learn of God's revelation), but also gives rise to questions that it may be important - even vital - to ask of their own tradition. He thus makes a case for exposure (a course, perhaps) to help establish the need and appetite for lifelong learning of theological students.

Firestone makes an excellent case for the "exposure" approach to interreligious education: adding a course, or a text, or a speaker about "another tradition" to help students recognize that the worldview that has shaped them is not inevitable, or the only option: that there are many approaches to the search for religious truth. This exposure model is very often an institution's first step toward interreligious education, and it is still prevalent, though the experiences of this volume's authors have led most of them to go beyond this model.

Tony Richie's arguments for a Pentecostal/Evangelical approach to interreligious education also deals directly with the resistance of many in his denomination. He, like some other Pentecostal and Evangelical theologians, seeks to maintain a strong commitment to high Christology and missiology with an openness to dialogue and interreligious education and relationships. These theologians turn to pneumatology (the Holy Spirit) to argue that Christ and God are not bound by the institutional church, but are at work everywhere, including in and through other religions. And they build on Pentecostalism's commitment to an affective experience of God and to lived Christianity as the goal of education to argue for an interreligious educational approach that leads Pentecostals out into the interreligious world to work alongside many others, including allies from other religions, against secularism and oppression of the marginalized. Given the history of the conservative rejection of other religions, these Pentecostal/Evangelical approaches have to include both a theology of religions (teaching students how to reconcile their Christian theological commitments with openness to other religions) and ministry in a multifaith context (providing alternative models of Christian hospitality to and partnership with adherents of other faiths). These pioneers in interreligious education are working against some resistance within their denominations, but they are providing leadership in both their teaching and their theological writings. 
These two essays are important in that they make relatively conservative cases for interreligious education, cases which honor the distinctive commitments and demands of their tradition while opening a careful door for interreligious engagement, because both their religious leaders and their members are living in a religiously diverse world. They illustrate how much interreligious pedagogy is necessarily shaped - both constrained and empowered-by its particular context. There is no one-size-fits-all model of interreligious pedagogy, as it must be embedded in the mission and values of the institutions in which it is practiced.

John Thatamanil writes from the progressive wing of Protestantism, from Union Theological Seminary in New York. His essay articulates a pedagogical approach to teaching interreligious theology. Leaving behind approaches of comparative theology (which compare texts or doctrines from two or more religions), he argues for a pedagogy that is not confined to the complications of doctrinal differences. Referencing Edward Farley, he argues for understanding theology, not as a narrowly cognitive discipline, but as "embodied wisdom," understood by observing the spiritual practices and disciplines of a religion, informed by its texts and teachings. He asks students to commit to the practices of another religion, and to reflect thoughtfully and critically on their experience. This experience gives them an "embodied appreciation" of the tradition, which is quite distinct from articulation of its doctrinal language. Note that practicing the wisdom of a tradition does not entail committing to a creed or an institution. Appreciation is not "belief": it is an aesthetic, affective, and embodied category. Pedagogical approaches to inter- or cross-religious practice are being developed in a number of settings. ${ }^{1}$ There may, of course, be instances when an individual does not feel comfortable engaging in such practices; it remains to be seen how such difficulties will be negotiated. The approach will depend on the source of the discomfort: cultural, affective or doctrinal. It should be noted that at Union Seminary, where Thatamanil teaches, there is an interreligious course on the liberative practices of Buddhism and Christianity, co-taught by a Buddhist monk and a Brazilian liberation theologian. Students are asked to create rituals/activities in which adherents of both religions can participate, focusing not on the easy commonalities, but on the

1 Louis Komjathy, who teaches at the University of San Diego, argues for embodied pedagogies of religion and interreligious learning. He requires students to commit to a practice for the semester, critically reflect on it, and to participate in at least one community event of the "other" religion they are studying. "Engaging Radical Alterity: Pluralism, Interreligious Dialogue, and Encountering 'Reality," in Teaching Interreligious Encounters, ed. Marc A. Pugliese and Alexander Y. Hwang (New York: Oxford University Press, 2017), 95-114. 
distinctive differences between the traditions. ${ }^{2}$ How or to what extent can those differences be negotiated?

\section{$2 \quad$ Complex Religious Identities}

One reason that interreligious education has become important in seminaries and theological schools is that student bodies are increasingly interreligious. Some seminaries and theological schools have programs and/or classes in which adherents of two or more traditions share the same course. Students of Asian, African, Oceanic, and Indigenous descent are increasingly aware that their personal and cultural identities have complex interreligious layers. And in many theological schools there are increasing numbers of "nones" (spiritual but not religious): students with a deep interest in religion, but with no desire for institutional affiliation and-sometimes-a complex mix of practices and beliefs. These complex religious identities challenge the traditional model of seminaries forming students in the school's denomination.

Recent developments in scholarship-particularly postcolonial, feminist, transnational, and ethnic studies-have made thoughtful students more aware of these complexities and issues.

Monica Coleman's essay demonstrates how the categories she was taught in graduate school to understand religious pluralism and diversity are not adequate for understanding African American religious identities. Beneath the surface of Christian membership of black churches are layers of African, indigenous, and folk practices that complicate an overly neat "Christian" identification. Her essay demonstrates the pedagogical assumptions and moves necessary to bring that richness into the classroom.

Christine Hong's essay deals with transnational (and, she argues, transspiritual) identities of migrants or Americans from other cultural backgrounds. She argues that to include such students fully in the classroom, pedagogy has to be rooted in students' specific stories and experiences, using the diversity of those stories as the core of their learning experience. Many teachers begin a seminary course with students sharing something about themselves, but Hong argues for a teaching model that builds from those stories. Such an approach is a very rich, student-centered approach. It challenges the teacher to help discover and articulate the "core" (shared insight) of the course and learning outcomes that will both affirm each student's experiences and challenge them to learn and grow in the diverse context. It also requires learning experiences

2 Interview with Greg Snyder, Union Theological Seminary, July 2, 2018. 
that will grow organically out of and be shaped by the diverse stories of the students. The nature and range of the diversity among the students will also affect the nuances of this approach: in some cases, the stories of other students may be quite familiar; in others, they may be dramatically different from anything the students have previously encountered.

\section{$3 \quad$ Muslim Perspectives}

One of our Muslim authors brings a very different approach to Muslim engagements in interreligious education: educating students for quite different roles. Timur Yuskaev teaches in a highly regarded program for Muslim chaplains at Hartford Seminary, an intentionally interreligious school with a long tradition of Muslim involvement. Although the Muslim students have their own courses in Quranic and legal teachings pertinent to chaplaincy, they take some basic ministry courses together with Christian and Jewish students. Yuskaev interviewed two graduates of the program in order to understand more deeply the impact of the interreligious dimensions of their education.

In his two case studies, the students brought their Muslim sensibilities and understandings to the pastoral situation, but both reported that their interreligious training in pastoral skills had been central in opening their insight into how to handle the situations with understanding and compassion. The interreligious sharing of ministry perspectives and experiences had honed their pastoral sensitivities in significant ways. This is significant, since most traditional Islamic education is text-based, pointing students to Quranic or legal texts which "speak to" a broad range of human issues. It is necessary and important to understand Islamic teachings on the situation, but sometimes in the moment it is the pastoral response that can cut to the heart of the issue, creating (in time, perhaps) a space for hearing the teaching of the tradition.

In one of the interviews for the mapping report, a Muslim doctoral student helping to develop broader principles for Muslim chaplaincy programs reported that during a visit to a hospital in the Middle East he asked Muslim health workers how they interacted with women who had miscarried. The health workers reported that they recited a hadith which argued for a longterm view of the loss from the perspective of Allah's mercy and blessing. He pointed out to them that, while the verse was certainly pertinent, these grieving women were in no state to take in that long-term perspective in their moment of intense grief. ${ }^{3}$

3 Kamal Abu-Shamsieh, personal communication, October 17, 2017. 
For some, like Yuskaev, interreligious education can train leaders from many religions to minister in a diverse world, and in particular, Muslims to minister in the United States, where there are established pastoral practices. Yuskaev's students benefited from interreligious courses teaching and adapting Christian pastoral practices to other religious and cultural environments.

For others, like the co-editor of this work, Najeeba Syeed, the primary motivation and goal of interreligious engagement is to bring persons of many religions together to create a better and more just world - to transcend the tendency of religious difference to create conflict and violence, and, on the contrary, come together to work for a better world that reflects many overlapping values. Syeed's teaching builds on liberationist pedagogies adapted to interreligious collaboration.

Research has shown that interreligious collaboration creates positive relationships, and is a powerful antidote to religious stereotypes and suspicion of religious others. Moreover, there are certainly issues on which interfaith/ interreligious groups have been able to collaborate, building a common space of shared experience and values. And these two are not diametrically opposed, as pastors, rabbis, and imams increasingly find themselves engaged in community projects to combat hunger, environmental degradation, or other social issues.

\section{Learning with Religious Others: Co-formation}

If in the early years of interreligious education in seminaries and theological schools the exposure model predominated (a course about, a text from, or a guest speaker from another religion), over time many institutions came to believe that effective interreligious pedagogy required engagement with religious others, learning with them and not just about them. Three of the essays in this volume particularly emphasize this development.

Nancy Fuchs Kreimer's essay reflects on the evolution of interreligious education at the Reconstructionist Rabbinical College in Philadelphia (RRC). After 9/11, the RRC decided that its rabbinical students needed both a well-grounded understanding of Islam and positive collaborative relationships with Muslims. They recruited students in Islamic Studies from the University of Pennsylvania for a joint program with their students, engaging in joint textual studies and in a collaborative educational project. Joint textual studies have been a key pedagogical approach to interreligious understanding. The RRC used the hevruta method, where pairs of students from the two religions study one another's texts, honoring the spiritual and interpretive traditions of their partners. 
Scriptural Reasoning is another widely adopted method in which interreligious groups read texts together, discovering the many readings that arise from intertextual conversation. ${ }^{4}$ The second part of the RRC program had pairs of Jewish and Muslim students develop an educational program which they could present in a Jewish institution. The program was training a cohort of educators who could address interreligious understanding in Jewish communities. Over time, as tensions over Israel and Palestine escalated, the RRC found it more difficult to recruit Muslim participants, and harder to persuade Jewish institutions to accept the Muslim-Jewish pairs for interreligious education. It thus revised its program to become one of spiritual refreshment and development for Jewish and Muslim leaders. In this new incarnation, groups of leaders meet for a program of self-reflection and shared spiritual practices that can renew those on the front lines of interreligious engagement. The new program is called "Cultivating Character: Conversations Across Communities."

The RRC story is one of thoughtful reflection on how the context of the broader society both constrains and helps define the needs of interreligious education. They have not pulled back from their conviction that Muslim and Jewish leaders need to know one another and their respective traditions in order to avoid the tensions that can arise between and toward groups. But they have continuously adapted their program and goals to changing circumstances, exploring various ways of learning with religious others.

Jennifer Peace, teaching at Andover Newton Theological Seminary, was convinced that in a multi-religious world theological formation had to be coformation: learning and growing spiritually toward leadership in partnership with religious others. Andover Newton had already entered into collaboration with their neighbor Hebrew College, offering joint courses, encouraging crossregistration among their students, and developing interreligious events shared by the campuses. They had developed a rich menu of interreligious opportunities for their students. Peace and her collaborator Or Rose took matters further by developing an interreligious fellows' program in which interreligious pairs or groups of students applied for a one-year fellowship to do a joint interreligious project-academic, artistic, or service. The fellows group had a joint seminar on leadership skills, and were mentored in developing their projects. The program developed strong interreligious collaborations. As Peace notes,

4 See Scriptural Reasoning, accessed March 23, 2018, www.scripturalreasoning.org, and Marianne Moyaert, "Interreligious Literacy and Scriptural Reasoning: Some Hermeneutical, Anthropological, Pedagogical and Experiential Reflections," in Teaching Interreligious Encounters, 95-114; also see part III of the same volume, Textual Encounters: Methods, Texts, and Traditions, $181-227$, for more text-based interreligious pedagogies. 
this program was not meant to be an add-on, but was to redefine the structure of theological education, putting co-formation at its very center.

Rachel Mikva of Chicago Theological Seminary traces the development of interreligious studies and engagement in the United States by comparing it with the "waves" of women's movements, and then uses those insights to reflect on interreligious education in her institution. Mikva was appointed to a newly-endowed chair in Jewish Studies at the seminary in 2009. After several years, she argued that effective interreligious education required the presence of students from diverse life stances, so the school developed a customizable degree program and expanded its recruiting base. Chicago Theological Seminary (CTS) has a strong commitment to social justice and community service, so interreligious collaboration for social justice was soon added to the program, with attention to the intersections of race, ethnicity, gender, class, and religion. Mikva's description of the CTS program thus intersects with many of the other essays I have already reviewed. What her essay also lifts up with particular clarity is that effective interreligious education requires a thoughtful transformation of Christian institutions. Many of the community structures, patterns of activities, and curricular structures were so thoroughly "Christian" that they were not sufficiently hospitable to interreligious education. That is to say that Cтs, like many institutions, had to attend to the implicit as well as the explicit curriculum of interreligious education-not just the content of courses, but how institutional structures and patterns either enabled or constrained interreligious education. As hospitable as many institutions aspire to be, the assumptions and structures of institutions and their curriculum are, as Dr. Seuss might say, "Christian all the way down." As institutions make a deep commitment to interreligious education, they have to re-examine many aspects of institutional and curricular practice. This requires honest institutional conversations and a commitment from the President and Board down through faculty and staff to make the necessary transformations.

\section{5}

\section{Issues to Consider}

The essays in this volume demonstrate thoughtful, critical reflection on the issues, approaches, and stakes of interreligious education by an experienced and committed cohort of leaders in the field. Yet, as any thoughtful readers will see, interreligious education is still a work in progress. While its history goes back decades, it has gained serious momentum only in the twenty-first century. As one faculty said to me in an interview, "I feel as if I am spinning, trying to see which way to go." That sums matters up quite well. 
As the essays demonstrate, the approaches to date have been shaped by the missions and characters of the institutions adopting them, and by larger developments in culture and society. As the role and shape of "religious" activity in the culture continues to morph and evolve, none of us can see far into the future of "religious" institutions and patterns, or of theological education. We are moving experimentally into an unknown future. Programs, practices, and institutions will continue to evolve.

This shifting ground can make it difficult to step back and reflect more deeply on interreligious education; we are too busy experimenting, adapting, and learning from successes and failures. Yet precisely because the ground is shifting, it is important to aspire to a deeper form of reflection. I want to raise three issues pertaining to the pedagogy of interreligious learning.

\section{Outcomes}

The first issue is: what are the intended outcomes of interreligious education? An astute reader will note that none of the essays directly addresses this issue, although they do suggest some implied outcomes.

When interreligious dimensions are added to a "standard" course in the theological curriculum, it is often as a form of enrichment. The standard learning outcomes of the course (defined by the curricular structure of the degree program) dwarf any interreligious outcomes. The interreligious activity "enriches" the course by adding a different perspective, or reminding students that there are other religious ways of addressing the issues addressed in the course.

The essays in this volume, however, articulate pedagogical approaches in which interreligious learning is more central to the course or educational program. Timur Yuskaev's essay documents how the pastoral practices taught in pastoral skills courses taken with Jewish and Christian students became central in the ability of Muslim chaplains to adapt Muslim teachings sensitively in pastoral situations. Tony Richie's essay illustrates how in Pentecostal/ Evangelical interreligious education it is necessary to address both theological and ministerial issues interreligiously in order to overcome historical resistance to "religious others." This seems to entail a learning outcome in which Christian theological and ministerial thinking can be adapted to interreligious settings.

John Thatamanil's approach to teaching interreligious theology invokes a broader understanding of theology as embodied wisdom in order to establish learning outcomes that are not about doctrinal understanding, but about 
embodied appreciation. How his approach assesses "embodied appreciation" is an intriguing issue, but it seems to involve both self-reflection and conversation.

Monica Coleman and Christine Hong both use student-centered pedagogies to help students articulate, understand, and claim their complex religious identities. In this approach, religious pluralism is both an intrapersonal reality and an external fact in the world. The learning approaches would seem to be related to self-understanding and articulation, and to engaging and affirming diversity through mutual conversation. It would be helpful to hear more about the sort of assignments (learning exercises) that comprise the arc of these courses.

For Jennifer Peace, interreligious pedagogy entails developing leadership skills and collaboration on projects. She uses experiential and collaborative learning to foster formation of leadership skills. Rachel Mikva's students also learn through collaborative action in the community.

Nancy Fuchs Kreimer's program focuses primarily on the learning outcomes desired for their rabbinical students, but also aims to benefit Muslim students and leaders. In the initial phase of their program, rabbinical students were asked to develop the knowledge and personal skills to be effective educators and leaders opposing the forces of Islamophobia. The learning outcomes were: (a) understanding the tradition and its texts; (b) establishing collaborative relationships; (c) developing educational programs for use in Jewish contexts. In their Cultivating Character program, students are already-established Jewish and Muslim leaders in need of renewal and inspiration for carrying on the work. The program is designed with outcomes for increased self-understanding, spiritual renewal, and establishing or deepening interreligious relationships.

Rachel Mikva's approach includes strong doses of critical analysis of the intersectional forces of oppression in society as a preparation for effective social action. While this outcome is not explicitly interreligious, it is arguably a foundation for more informed and effective interreligious collaboration for justice, reminding students that religion is only one factor in a complex social situation.

\section{Metrics for Assessment}

What these essays do not offer is specific information on how to articulate and measure/assess those learning outcomes: what are the metrics? The current literature on interreligious education is, regretfully, somewhat thin on metrics. Eboo Patel's Interfaith Youth Corps has made assessment planning and training central to its institutional grants, but I have seen no published data about 
what form such assessments take. Patel evaluates his own programs for community leaders on three vectors: changes in attitudes, development of relationships, and knowledge about other traditions. ${ }^{5}$ The Jesuit School of Theology at Santa Clara University has adapted Early and Ang's "cultural intelligence" (CQ) assessment tool for evaluating interreligious intelligence: it uses a Likert scale for "before/during/after" responses and a free response section. ${ }^{6}$ These are promising beginnings, but we need more literature on methods for assessing interreligious learning.

Sustainability

Interreligious education is expanding rapidly into a broad range of institutions as we seek to educate leaders and citizens to contribute to an increasingly religiously diverse society. Such education is recognized as significant and seems to be gaining momentum, but there are serious challenges of sustainability.

First, there are the economic strains on and the fragility of many theological institutions. As Heidi Hadsell shares in her essay, these strains have encouraged theological schools to open their spaces and their doors to students beyond their original denominations. But many theological institutions are fragile. In the years I was researching my report mapping interreligious education, three of twenty-four schools I studied either closed or moved into another institution, and two very successful programs were ended because of financial difficulties. Interreligious education is caught in the midst of these ground shifts; for some institutions it may be a way to strengthen the school's mission as it moves into the future, and for others, it may be seen as a distraction. The challenge is to redefine or expand a school's mission while affirming its core values. As both Heidi Hadsell's and Rachel Mikva's essays demonstrate, a core commitment to interreligious education may require considerable institutional transformation.

Second, there is the issue of faculty resources. Too often interreligious education rests on the shoulders of a single faculty leader. If that leader leaves, the program collapses. And, as interreligious issues have special resonance with faculty of Asian, African, Oceanic, or Indigenous descent, this issue may be added to the considerable burdens they already carry.

5 Eboo Patel, Interfaith Leadership: A Primer (Boston: Beacon University Press, 2016), 100-101.

6 Marianne Farina and Robert W. McChesney, "A Contextual Model for Interreligious Learning," in Teaching Interreligious Encounters, 287. 
The need for faculty leadership in the field raises the issue of graduate formation of faculty for interreligious education. There are few doctoral programs which ground faculty both in theological disciplines and in interreligious skills; and there is thus an inadequate pipeline of faculty to lead this work. Because of lack of training in doctoral programs, many faculty who take on interreligious education need additional support to develop interreligious courses and approaches.

The doctoral program at the Graduate Theological Union in Berkeley is now organized into four interreligious departments, with required interreligious departmental seminars. The departments are: Sacred Texts and their Interpretation; Historical Studies; Theology and Ethics; Religion and Practice. This is a recent reorganization of the GTU's program away from a Christian-dominated structure; GTU faculty are still negotiating the challenges of living into the requirements of the new program. Yet this is an important experiment, as it is one step toward the development of theological faculty with interreligious skills.

Despite the challenges and the work yet to be done, the essays in this volume amply demonstrate the promise and vitality of interreligious education. With new professional organizations, a presence on the program of the American Academy of Religions, and journals through which to share developing knowledge, this initiative is bound to thrive 